\title{
Low dose famotidine and cimetidine in single postprandial doses: a placebo controlled comparative study of overnight $\mathrm{pH}$
}

\author{
T G Reilly, S G Mann, M Z Panos, R P Walt
}

\begin{abstract}
To investigate the relative abilities of low doses of famotidine and cimetidine to raise intragastric $\mathrm{pH}$ after a single postprandial evening dose, 16 healthy volunteers were recruited to a four period crossover trial of famotidine $10 \mathrm{mg}$, cimetidine $100 \mathrm{mg}$ and $200 \mathrm{mg}$ compared with placebo. Intragastric $\mathbf{p H}$ was monitored between 1800 and 0730 with a nasogastric pH electrode. Median gastric pH rose from 1.35 (interquartile range $1 \cdot 1-1 \cdot 65$ ) with placebo to $1.95(1.6-5 \cdot 35, \mathrm{p}<0.001$ Friedman rank) after dosing with famotidine $10 \mathrm{mg}$, to $1.46(1 \cdot 3-2 \cdot 0,0 \cdot 05<\mathrm{p}<0 \cdot 1)$ after cimetidine $200 \mathrm{mg}$, and remained $1.35(1 \cdot 1-1 \cdot 6, \quad p>0 \cdot 2)$ after cimetidine $100 \mathrm{mg}$. Intragastric $\mathbf{p H}$ was above 3 for $34 \%(p<0.005)$ of the time after dosing with famotidine, compared with $13.6 \%$ (p>0.2) after cimetidine $200 \mathrm{mg}, 9.5 \%$ $(p>0.2)$ after cimetidine $100 \mathrm{mg}$, and $4.7 \%$ after placebo. The rise of intragastric $\mathbf{p H}$ after famotidine $10 \mathrm{mg}$ is significantly greater than that after either $200 \mathrm{mg}$ or $100 \mathrm{mg}$ cimetidine when the drugs are used postprandially.

(Gut 1995; 37: 325-328)
\end{abstract}

Keywords: $\mathrm{H}_{2}$ receptor antagonist, intragastric $\mathrm{pH}$, famotidine, cimetidine.

Low dose $\mathrm{H}_{2}$ receptor antagonists have recently been marketed for 'over the counter' use in dyspepsia. They are recommended for postprandial and nocturnal dyspepsia and acidity. It is assumed that the symptomatic responses of dyspeptic patients will relate directly to the antisecretory effects of these agents and thus the pharmacodynamic activity of the drugs may be used as a surrogate measure of clinical efficacy. We therefore sought to compare the antisecretory properties of famotidine $10 \mathrm{mg}$ (Pepcid AC, Centra Healthcare), cimetidine $100 \mathrm{mg}$ and $200 \mathrm{mg}$ (Tagamet, SKB) in a controlled study. The relative antisecretory effect of such doses has not previously been published.

\section{Methods}

Subjects

Sixteen healthy subjects (eight males, eight females) median age 21 years (range 19-25) and median weight $71 \mathrm{~kg}$ (range 53-80) were recruited into the study. The subjects included four smokers who were able to abstain from smoking on the days of the study. Median weekly ethanol consumption ascertained by questionnaire was 13 units (range 0-30). Each volunteer gave his or her written informed consent and the study protocol was approved by South Birmingham Health Authority Ethics Committee.

\section{Study design}

The investigation was designed as a four period crossover study with all subjects receiving the four different preparations in a random order. The study was partially blinded in that the drugs were recognisably different but the subjects were not aware of which was which. Of the two principal investigators one (RPW) was blinded to the drugs. There was a wash out period of at least six days between studies.

On each study day subjects arrived at 1700 on the investigation unit having fasted for six hours. Bipolar glass $\mathrm{pH}$ electrodes (Ingold M440) were calibrated in standard buffer solutions of $\mathrm{pH} 7.00$ and 4.01 and calibration was verified at $\mathrm{pH} 1 \cdot 69$. These electrodes were passed by the nasogastric route. A drop in $\mathrm{pH}$ to less than 2 was taken as evidence of the tip of the probe having entered the stomach, and the electrode was advanced a further $8 \mathrm{~cm}$ from this point. At 1830 a standard meal was given, which consisted of a supermarket ready meal of cottage pie, peas, and carrots, followed by chocolate coated ice cream and two chocolate mints to give a total of $700 \mathrm{kcal}$, provided by $22 \mathrm{~g}$ protein, $70 \mathrm{~g}$ carbohydrate, and $37 \mathrm{~g}$ fat, accompanied by $250 \mathrm{ml}$ mineral water. The drugs were given as tablets (famotidine 10 $\mathrm{mg}$ and cimetidine $200 \mathrm{mg}$ ) or as elixir (cimetidine $100 \mathrm{mg}$ ) with $50 \mathrm{ml}$ mineral water at 1930. The placebo was a tablet containing no active ingredient. Subjects had nothing further to eat before the end of the study period, but had a further $250 \mathrm{ml}$ of mineral water at 2100 . The subjects retired to bed at 2300 and the $\mathrm{pH}$ electrodes were removed at 0730 after an overnight stay on the investigation unit under the supervision of one of the investigators (TGR).

Analysis of data

pH measurements were recorded using GastrograpH recorders (Medical Instruments Corporation, Solothurn, Switzerland). These instruments measure the potential difference between the electrode and the reference electrode in the tip of the tube four times per
Dr R P Walt, Birming

Boardsley Green East,

Birmingham B9 5SS.

Accepted for publication

18 January 1995 


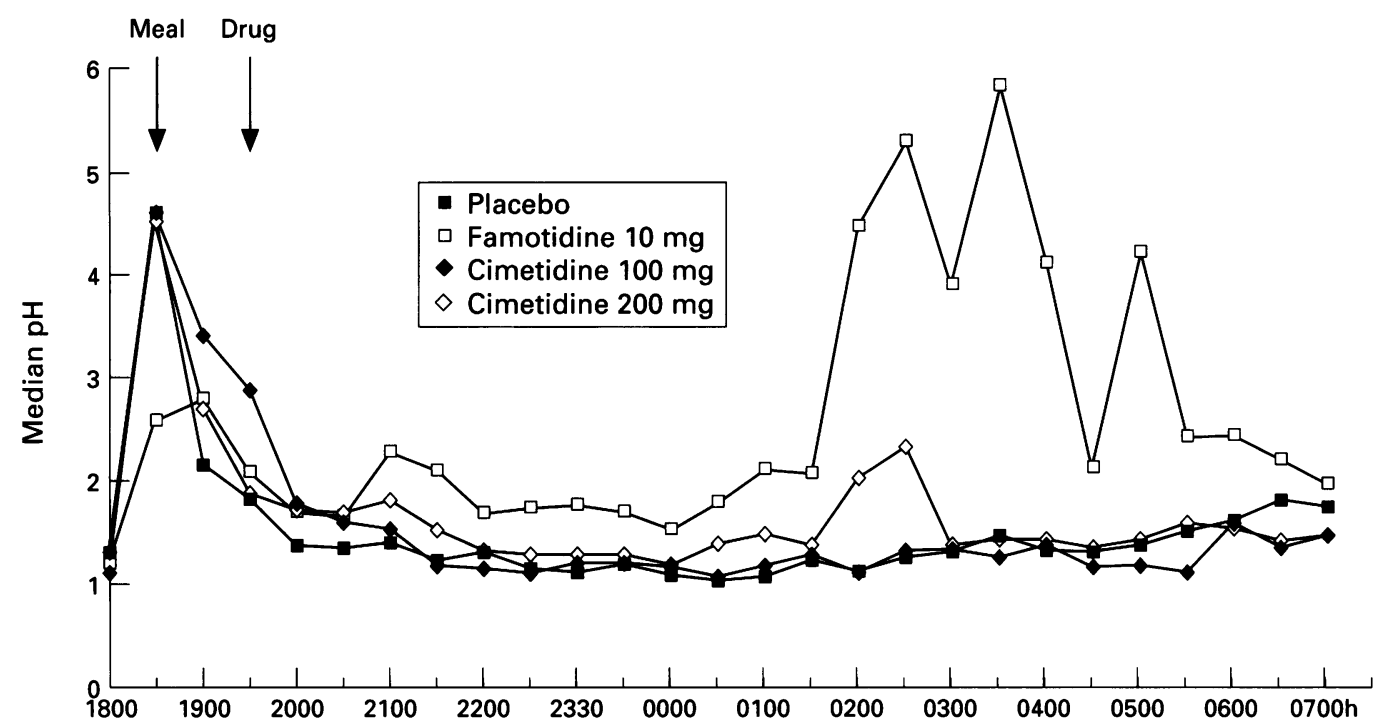

Figure 1: Half hourly median $p H$ for four different treatments. These plots represent the median values of 16 individual half hourly medians.

second. Median $\mathrm{pH}$ values are stored giving data on $\mathrm{pH} 10$ times per minute. The data were transferred to a computer for graphic and numerical analysis. Half hourly medians for each study period were extracted from the raw data and all subsequent data summaries and analyses were based on these half hourly medians. Friedman's rank test based on the $\chi^{2}$ distribution was used to compare different treatments.

The principal study periods analysed were as follows: the period from the drug being given to the end of the study (drug to end); and from the drug to seven hours (drug plus 7). Secondary descriptive analyses were performed in an attempt to define onset of action using the periods from drug administration to one hour, $1 \frac{1}{2}$ hours, and two hours after dosing.

\section{Results}

Sixteen volunteers participated in all parts of the study. On two occasions in two different volunteers an error in programming the
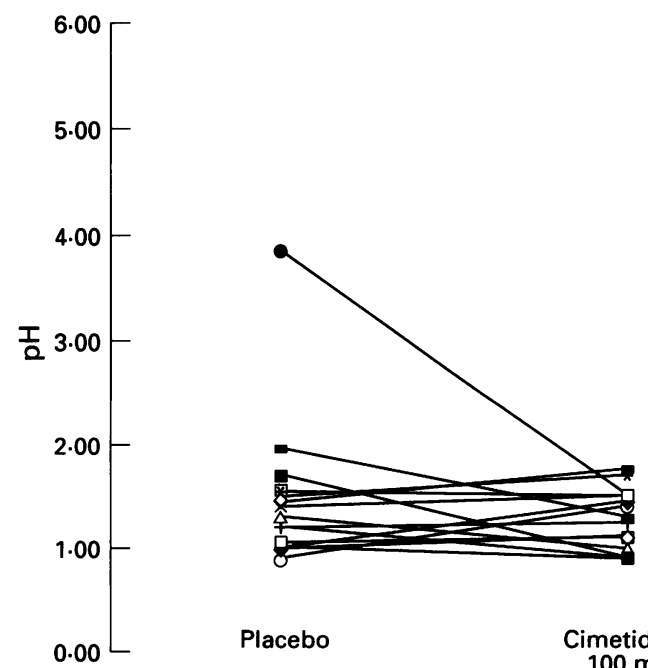

Figure 2: Median pH placebo comparisons for 16 subjects after cimetidine $100 \mathrm{mg}$ : drug to end period. recording device necessitated a study being repeated. On both occasions the finishing time was incorrectly entered so that on the first occasion the recording ceased at midnight, and on the second it ceased at 0630 . On both occasions the repeat study was the one used for analysis. All studies were well tolerated and no significant adverse events were reported during or after any study.

Figure 1 shows the group median half hourly $\mathrm{pH}$ over the whole study period for all studies and shows that $\mathrm{pH}$ rose substantially after famotidine and less after cimetidine $200 \mathrm{mg}$. The $\mathrm{pH} /$ time curve after cimetidine $100 \mathrm{mg}$ was indistinguishable from that with placebo. The period when the difference between the $\mathrm{H}_{2}$ receptor antagonists was most easily visualised was from seven hours after the drug administration.

\section{Primary analyses}

Drug to end - Figures 2-4 show the individual median $\mathrm{pH}$ values from drug administration to the end of the study for all dosings

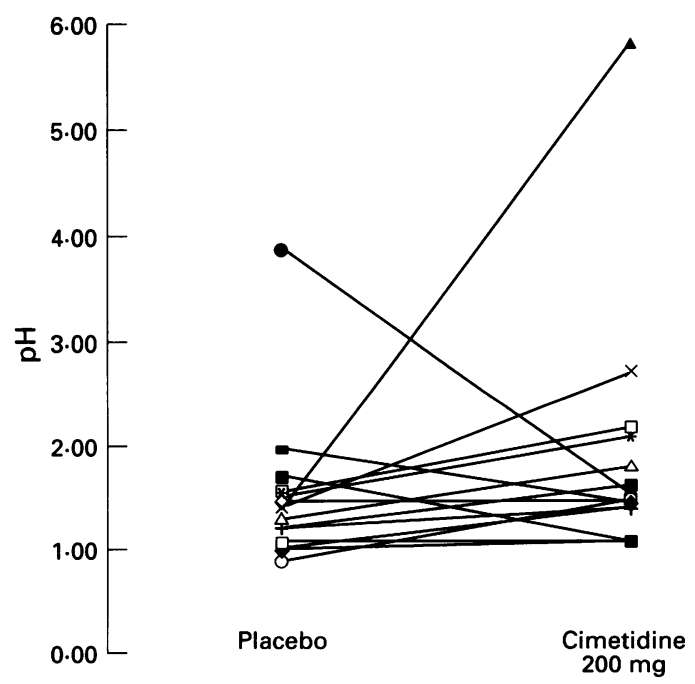

Figure 3: Median pH placebo comparisons for 16 subjects after cimetidine $200 \mathrm{mg}$ : drug to end period. 


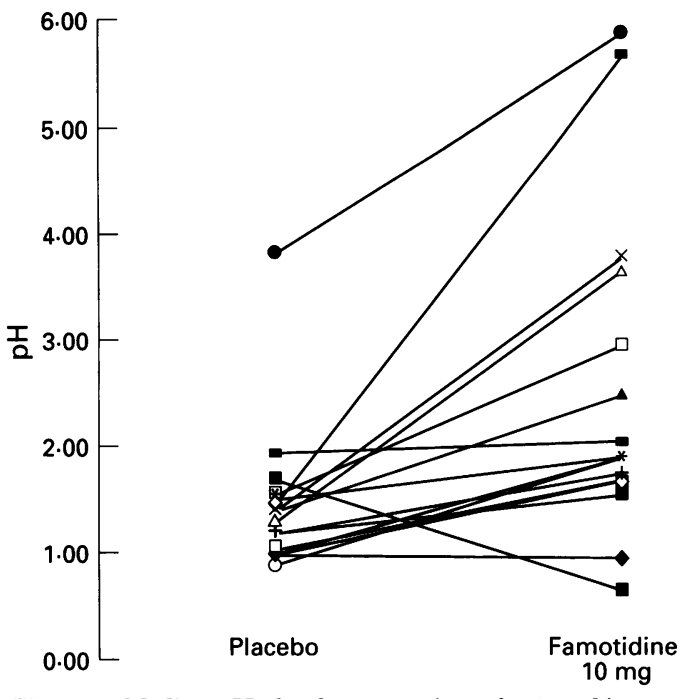

Figure 4: Median pH placebo comparisons for 16 subjects after famotidine $10 \mathrm{mg}$ : drug to end period.

for the different drugs. After placebo the group median $\mathrm{pH}$ (interquartile range) was 1.35 (1.1-1.65); after cimetidine $100 \mathrm{mg}$ it was 1.35 ( $1 \cdot 1-1 \cdot 6 ; p>0 \cdot 2$ compared with placebo); after cimetidine $200 \mathrm{mg}$ it was $1.46(1 \cdot 3-2 \cdot 0$; $0.05<\mathrm{p}<0.1)$; and after famotidine $10 \mathrm{mg}$ it was $1.95(1.6-5.35 ; \mathrm{p}<0.001)$. We examined the proportion of time that gastric $\mathrm{pH}$ was above 3 and 4 for each drug (Table). The proportion of time above both $\mathrm{pH}$ values was statistically significantly greater with famotidine $10 \mathrm{mg}$ than placebo; differences with both doses of cimetidine did not reach statistical significance.

Drug to seven hours - As the half life of cimetidine is comparatively short (two hours) any effects of the drug may have worn off well before the end of the study. We therefore analysed the data from dosing up to seven hours. Compared with placebo, median $\mathrm{pH}$ was raised by famotidine $10 \mathrm{mg}$ from 1.25 to $1.8(\mathrm{p}<0.005)$; after cimetidine $200 \mathrm{mg}$ to $1.39(0.05<\mathrm{p}<0.1$, not significant $)$, and there was no significant difference between placebo and cimetidine $100 \mathrm{mg}(1.25 v 1 \cdot 25, \mathrm{p}>0 \cdot 2)$. The area under the $\mathrm{pH} /$ time curve from drug to seven hours after dose showed a significant difference from placebo for both famotidine $10 \mathrm{mg}(\mathrm{p}<0.0001)$ and cimetidine $200 \mathrm{mg}$ $(\mathrm{p}<0.01)$.

\section{Descriptive analyses}

To assess the onset of significant activity we compared the effects of cimetidine $200 \mathrm{mg}$ and famotidine $10 \mathrm{mg}$ with placebo at earlier times after drug administration. Famotidine $10 \mathrm{mg}$ showed a significant difference at two hours $(p<0.02)$ but not before. After cimetidine $200 \mathrm{mg}$ we could not show a significant difference from placebo at any time when the median $\mathrm{pH}$ was used for analysis.

\section{Discussion}

Low dose preparations of $\mathrm{H}_{2}$ receptor antagonists are of interest at present because they have recently become available to the public without prescription as over the counter drugs. This study sought to show whether there were differences in the pharmacodynamic activities of famotidine $10 \mathrm{mg}$, cimetidine $100 \mathrm{mg}$, and cimetidine $200 \mathrm{mg}$. In planning this investigation we designed a protocol that would closely mimic the use of these drugs for self treatment. We believe that postprandial heartburn is the symptom for which these drugs are likely to be used and therefore arranged to study the effects of the drugs taken soon after a realistically typical evening meal rather than at bedtime or in the fasted state. Healthy volunteers rather than patients were used for practical reasons and because in many cases self treatment would be by subjects otherwise recognised as normal. We did not include any snacks after the main meal as eating after the evening dose of an $\mathrm{H}_{2}$ receptor antagonist has been shown greatly to reduce the effectiveness of the drug. ${ }^{1-3}$ We timed the dose at one hour after the meal in a further attempt to mimic the symptomatic use of the drug postprandially. It is recognised that an early evening dose with potent $\mathrm{H}_{2}$ antagonists produces more acid inhibition than bedtime administration. ${ }^{4}$

Famotidine $10 \mathrm{mg}$ raised $\mathrm{pH}$ significantly versus placebo over the whole postdose period while the less potent drug (cimetidine) did not achieve this. After dosing with famotidine $10 \mathrm{mg}$ a significant difference in median $\mathrm{pH}$ compared with placebo was found at two hours but after cimetidine $200 \mathrm{mg}$ we could not show a significant difference. Reference to the curve of median $\mathrm{pH}$ against time (Fig 1), however, shows that cimetidine $200 \mathrm{mg}$ clearly does have an effect on acidity, and by using the area under the $\mathrm{pH} /$ time curve it is possible to show a significant difference from placebo for this drug over the seven hour period $(p<0 \cdot 01)$.

There is debate as to which measure of central tendency should be used in studies such as this: we have used the median because, unlike the mean or the area under the curve, it

Placebo comparisons between four different drug regimens over three periods by median $p H$ and percentage of time that gastric $\mathrm{pH}$ was above 3 and 4

\begin{tabular}{|c|c|c|c|c|c|c|c|c|c|c|c|c|}
\hline & \multicolumn{4}{|c|}{ Whole period } & \multicolumn{4}{|c|}{ Drug to end } & \multicolumn{4}{|c|}{ Drug to +7 hours } \\
\hline & $P$ & $C 100$ & $C 200$ & $F 10$ & $P$ & $C 100$ & $C 200$ & $F 10$ & $P$ & $C 100$ & $C 200$ & $F 10$ \\
\hline $\begin{array}{l}\text { Median } \\
\mathrm{pH} \\
\mathrm{pH}>3 \\
(\% \text { time }) \\
\mathrm{pH}>4 \\
(\% \text { time })\end{array}$ & $\begin{array}{l}1 \cdot 35 \\
9 \cdot 6 \\
5 \cdot 75\end{array}$ & $\begin{array}{c}1.4 \\
\mathrm{p}>0.2 \\
12.25 \\
\mathrm{p}>0.2 \\
7.45 \\
\mathrm{p}>0.2\end{array}$ & $\begin{array}{c}1.5 \\
\mathrm{p}>0.05 \\
14.75 \\
\mathrm{p}>0.2 \\
8.2 \\
\mathrm{p}>0.2\end{array}$ & $\begin{array}{c}2.0 \\
\mathrm{p}<0.001 \\
32.25 \\
\mathrm{p}<0.001 \\
27.6 \\
\mathrm{p}<0.005\end{array}$ & $\begin{array}{l}1.35 \\
4.65 \\
1.65\end{array}$ & $\begin{array}{c}1.35 \\
\mathrm{p}>0.2 \\
9.45 \\
\mathrm{p}>0.2 \\
4.75 \\
\mathrm{p}>0.2\end{array}$ & $\begin{array}{r}1.46 \\
\mathrm{p}>0.05 \\
13.6 \\
\mathrm{p}>0.2 \\
8.3 \\
\mathrm{p}>0.2\end{array}$ & $\begin{array}{c}1.95 \\
\mathrm{p}<0.001 \\
34.1 \\
\mathrm{p}<0.005 \\
29.1 \\
\mathrm{p}<0.005\end{array}$ & $\begin{array}{l}1 \cdot 25 \\
5 \cdot 45 \\
2 \cdot 3\end{array}$ & $\begin{array}{c}1.25 \\
\mathrm{p}>0.2 \\
7.3 \\
\mathrm{p}>0.2 \\
4.25 \\
\mathrm{p}>0.2\end{array}$ & $\begin{array}{c}1.39 \\
\mathrm{p}>0.05 \\
12.0 \\
\mathrm{p}>0.2 \\
4.45 \\
\mathrm{p}>0.2\end{array}$ & $\begin{array}{c}1.8 \\
\mathrm{p}<0.005 \\
22.75 \\
\mathrm{p}<0.005 \\
15.75 \\
\mathrm{p}<0.005\end{array}$ \\
\hline
\end{tabular}

All tests Friedman rank based on $\chi^{2}$ distribution. $\mathrm{P}=$ placebo; $\mathrm{C} 100=$ cimetidine $100 \mathrm{mg} ; \mathrm{C} 200=$ cimetidine $200 \mathrm{mg}$; $\mathrm{F} 10=$ famotidine $10 \mathrm{mg}$. 
permits direct comparison of $\mathrm{pH}$ and hydrogen ion concentration. As far as cimetidine $200 \mathrm{mg}$ is concerned it is reasonable to suppose that a statistically significant difference shown by one method but not by another is unlikely to represent a difference of any clinical significance.

Cimetidine $100 \mathrm{mg}$ had little effect on postprandial intragastric $\mathrm{pH}$. A possible criticism of our method is that the liquid form used in the study has a different bioavailability from the tablet form available over the counter. While no published data exist for the $100 \mathrm{mg}$ dose of cimetidine, a comparative study $y^{5}$ found that a $300 \mathrm{mg}$ tablet of cimetidine was bioequivalent to a $300 \mathrm{mg}$ dose of oral liquid, and it may be supposed that this relation holds good for the lower dose.

These results suggest that in the doses tested famotidine acts for longer than cimetidine.

The greatest rise in $\mathrm{pH}$ after famotidine $10 \mathrm{mg}$ was seen after seven hours and fits with previous data on the effects of $\mathrm{H}_{2}$ antagonists overnight. During this period, competition at $\mathrm{H}_{2}$ receptors between drug and histamine is likely to be minimal because by this time food stimulated acid secretion will have worn off and the diurnal pattern of acid secretion will have passed its peak ${ }^{67}$ but substantial plasma drug concentrations will remain. It is also the period when in healthy stomachs spontaneous late night gastric alkalinisation is encountered. ${ }^{8}$ The surprising finding is the difference between the effect of cimetidine $200 \mathrm{mg}$ and famotidine $10 \mathrm{mg}$. Famotidine is about 20 times as potent as cimetidine on a weight to weight basis, and it would therefore have been expected that the doses tested would be equipotent. $^{9}$

In a previous study inhibition of meal stimulated acid secretion was seen within 90 minutes, and the range of mean $\mathrm{pH}$ values obtained was $2 \cdot 0-2 \cdot 3$ between 1.7 and $3 \cdot 2$ hours postdose after oral famotidine $10 \mathrm{mg} .^{10}$ These results are in accord with our findings, which additionally show for how long this drug is able to raise intragastric $\mathrm{pH}$. Our study was not primarily designed to determine the onset of action, which would require further study and it is probable that the drugs were actively inhibiting acid secretion well before any detectable change in acidity. During the first two hours after a meal food in the stomach tends to buffer acid secretion hence obscuring drug action, so it is possible that both drugs were active earlier than our results would suggest.

Our results differ, however, from the only other study of low dose cimetidine in healthy volunteers. ${ }^{11}$ That earlier study showed that low doses of cimetidine (100 mg and $200 \mathrm{mg}$ ) taken at 2300 reduced nocturnal acid secretion over an eight hour period in nine healthy fasted subjects, achieving for both preparations intragastric $\mathrm{pH}$ values of above $\mathrm{pH} 3$ for $100 \%$ of the time. Methodological differences can probably explain the apparent variance of results.
This study differed substantially from our own: the volunteers were fasted, the investigation only lasted eight hours and started late at night when the stomach should be resting, and continuous aspiration of gastric contents gave measurements of basal acid secretion rather than acidity. Other studies that have looked at low dose cimetidine have found less impressive inhibition of acid secretion, but have used duodenal ulcer patients and are hence not strictly comparable. ${ }^{1213}$

One subject showed no response to any of the drugs and it is likely that he was a nonresponder to $\mathrm{H}_{2}$ receptor antagonists. ${ }^{14}$ This finding re-emphasises the known wide variation of response within populations. Such variation in dose requirement is most noticeable with low doses and could influence symptomatic efficacy if the proportion of nonresponders is great. It is expected that these over the counter drugs will be used in response to symptoms and it is likely that their effect will mirror their antisecretory activity. We conclude that famotidine $10 \mathrm{mg}$ is more effective than either cimetidine $100 \mathrm{mg}$ or $200 \mathrm{mg}$ at raising intragastric $\mathrm{pH}$ with a single dose taken after a normal evening meal.

This study was funded by a grant from Merck Research Laboratories. The authors thank Sister Annette Huggins and the staff of the Clinical Investigations Unit, Queen Elizabeth Hospital, Birmingham for their support.

1 Johnston DA, Wormsley KG. The effect of food on ranitidine-induced inhibition of nocturnal gastric secretion. Aliment Pharmacol Ther 1988; 2: 507-11.

2 Merki HS, Halter F, Wilder-Smith C, Allemann P, Witzel $\mathrm{L}$, Kempf $\mathrm{M}$, et al. Effect of food on $\mathrm{H}_{2}$ receptor blockade in nemp $\mathrm{M}$, et al. Enfect of food on $\mathrm{H}_{2}$ receptor blockade 31: $148-55$.

3 Hannan A, Chesner I, Mann S, Walt R. Can $\mathrm{H}_{2}$-receptor blockade completely abolish food stimulated acid secreblockade completely abolish food stimulated acid secretion? European

4 Lanzon-Miller S, Pounder RE, McIsaac RL, Wood JR. The timing of the evening meal affects the pattern of 24-hour intragastric acidity. Aliment Pharmacol Ther 1990; 4: 547-53.

5 Walkenstein SS, Dubb JW, Randolph WC, Westlake WJ, Stote RM, Intoccia AP. Bioavailability of cimetidine in man. Gastroenterology 1978; 74: 360-5.

6 Feldman M, Richardson CT. Total 24-hour gastric acid secretion in patients with duodenal ulcer: comparison with normal subjects and effects of cimetidine and parietal with normal subjects and effects of cimetidine and

7 Sanders SW, Moore JG, Day GM, Tolman KG. Circadian differences in pharmacological blockade of mealdifferences in pharmacological blockade of meal1992; 6: 187-93.

8 Bianco A, Cagossi M, Piraccini R, Greco AV. Twenty-fourhour intragastric $\mathrm{pH}$-metry: $\mathrm{H}_{2}$-receptor antagonist restoration of nightly gastric spontaneous alkalinization in duodenal ulcer healing. Riv Eur Sci Med Farmacol 1992, 14: 281-91.

9 Echizen H, Ishizaki T. Clinical pharmacokinetics of famotidine. Clin Pharmacokinet 1991; 12: 178-84.

10 Laskin OL, Patterson P, Shingo S, Lasseter KC, Shamblen EC. Pharmacodynamics and dose-response relationship of. Pharine: a double-blind randomised placeboof famotidine: a double-blind randomised placed trial. f Clin Pharmacol 1993; 33: 636-9.

11 Action G, Broom C, Wareham K, Laroche J, Burnham D, Friedman $C$. Effects of low-dose cimetidine on nocturnal Friedman $\mathrm{C}$. Effects of low-dose cimetidine on nocturnal 1991; 5: 61-7.

12 Hollander D, Hossain Z, Sufi A. Inhibition of nocturnal acid secretion in duodenal ulcer patients by an $\mathrm{H}_{2}$-histamine antagonist-cimetidine Dig Dis 1976; 21: 361-70.

13 Blackwood WS, Northfield TC. Nocturnal gastric acid secretion: effects of cimetidine and interactions with anticholinergics. In: Burland WS, Simkins MA, eds. Cimetidine: proceedings of a second international symposium on $\mathrm{H}_{2}$-receptor antagonists. Amsterdam: Excerpta Medica, 1977: 124-30.

14 Hunt RH. Non-responders to cimetidine treatment. Part 1. In: Baron JH, ed. Cimetidine in the 80's. Edinburgh: Churchill Livingstone, 1981: 34-41. 